\title{
Nepochopená setkání: sémiotika a sociální věda o médiích
}

\section{General Misunderstandings: Semiotics and Media Studies}

\author{
Martin Švantner
}

\begin{abstract}
The main goal of this mostly theoretical and polemic paper is to discuss common mistakes connected to misinterpreted theories of signs in selected theoretical researches in the discourse of Czech media studies. I argue that many theoretical concepts in this discourse are built upon confusions caused by the reading of secondary literature while ignoring the primary texts written by the founders of semiotics. The guiding principles of these mistakes, which are described in the article, have mostly two forms: i) the form of reducing Peirce's complex semiotic theory to the triplet (popularized by Jakobson) of alleged similarity (in the case of sign-icon), causality (in the case of the sign-index) and convention (sign-symbol); and ii) the form of interpretation of Saussure's purely mental sign as something which has in itself "materiality of sound" (ergo the signifier is something physical). I would like to show that the original conceptions of semiotics and semiology have nothing to do with these wild misreadings of secondary sources that, moreover, cannot be crossbred, which brings problems into the theoretical frames of research.
\end{abstract}

KEY WORDS semiotics, epistemology, media studies, Peirce, Saussure, ethic of terminology

\section{Úvod}

Cílem této teoretické studie ze žánru kritické epistemologie sociálních věd je poukázat na některé problémy vyvěrající z neporozumění a z někdy chybného, svévolného nebo nepřesného užívání základních konceptů teorie znaku mimo obor sémiotiky. Abychom mohli kritiku zavádějících (v závěru ukázaných) interpretací přesvědčivě ujasnit, je třeba prvně analyzovat vybrané aspekty dvou zcela základních textů, tj. míst ze Saussurova a Peircova korpusu. Exegeze se tedy pojí s obratem k pramenům základních sémiotických textů, které byly zaneseny vrstvami interpretací a někdy systematicky zapomenuty. Článek se snaží být konkrétním a zároveň kritickým př́spěvkem k obecné sémiotice, tzn.:

i) být analýzou vybraných aspektů dvou základních paradigmat znakové teorie (tj. Saussurovy sémiologie a Peircovy sémiotiky) vymezujících do velké míry to, jak lze v nejvyšší míře obecnosti uvažovat o zastupování něčeho něčím jiným";

Sociální studia / Social Studies 2/2017. S. 99-122. ISSN 1214-813X.

1 Tedy analýzou základních paradigmat vymezujících jak z hlediska abstraktního systému popisu reprezentace, tak z hlediska historického dopadu na další humanitně a sociálně vědní odvětví. Jak uvidíme níže, tato teze je předběžná, jelikož zastupování „něčeho něčím dalším“ se u těchto dvou velkých teoretických perspektiv značně odlišuje. 
ii) být kritikou níže tematizovaných vybraných aplikací (kvazi)sémiotické a (kvazi)sémiologické perspektivy v epistemologiích sociálních věd, které se často prezentují tak, jako by byly vystavěny na obecně sémiologických a sémiotických předpokladech. Základním východiskem pro komparaci nejprve základních paradigmat a posléze výsledků této analýzy s dalšími texty je formální pojetí znaku jakožto specifické relace, kterou každé z níže analyzovaných paradigmat (sémiologie a sémiotiky) tematizuje naprosto odlišně.

Je třeba předeslat, že text je vzhledem ke svému rozsahu pochopitelně reduktivní a výklad základních paradigmat je veden účelně ve vztahu $\mathrm{k}$ vybraným interpretacím v sociálních vědách. Dílčím cílem textu je ukázat, že znalost základních textů je pro funkčnost další aplikace těchto základních teoretických východisek nejen důležitá, ale také závazná. Ve druhé části pak podávám předběžný výčet některých omylü, rozporných tvrzení a konceptuálních nekonzistencí, které jsou $\mathrm{v}$ rámci specifických teoretických užití tradovány a traktovány. Zprvu je tak nutné podat analýzu vybraných pasáží pramenných textů. Závěr pak představuje prímou demonstraci a kritiku konkrétních, ve druhé části analyzovaných, často přejímaných zkreslení. Hlavní osten kritiky je zaměřen na vybrané texty z prostředí českých mediálních studií, které se mnohdy považují za proponenty tzv. sémiotické analýzy, pod kterou se pseudo-synteticky zařazují často mimoběžné teoretické koncepty. Obecným cílem textu je posloužit lepšímu pochopení Saussurova a Peircova díla v současné sociálně vědní epistemologii a poukázat na kličové problémy, které se v českém prostředí s (dez)interpretací základních sémiotických textů pojí.

\section{Práce s prameny}

Je třeba nejprve rozlišit několik typů interpretačních odstupů a poukázat na jisté filologické a hermeneutické problémy, se kterými $\mathrm{k}$ sémiotice přistupujeme. Za prvé je třeba si uvědomit, že zde máme rozsáhlé korpusy základních textů „otců zakladatelưu, kteří, ač jsou autory fin de siècle, mají dalekosáhlý vliv na mnohé současné sociálně vědní perspektivy. Na jedné straně barikády tak stojí lingvista Ferdinand (Mongin) de Saussure (1857-1913), a na druhé polyhistor Charles Sanders (Santiago) Peirce (1839-1914).

Prvně je třeba zdůraznit, že samotný výraz „znak“ je zavádějící z toho důvodu, že se pod tento termín zahrnují odlišné významové obsahy. V našem případě jde o typy relací, které kombinují paradigmaticky jiné prvky. Předběžně můžeme říci, že:

a) v prípadě strukturální sémiologie spojené se Saussurem se jedná o dyadickou nominalistickou transcendentální relaci dvou diferenčně vymezených mentálních obsahů;

b) V prípadě anglosaské sémiotické tradice spojené s Peircem jde o realistickou ontologickou triadickou relaci objektu, znaku a mysli, která je vystavěna ${ }^{2}$ na Peircově teorii kategorií.

Alespoň co se týká Peircovy tzv. pozdní sémiotiky - tj. vybudované okolo roku 1900 (srov. Short 2007; Švantner 2014b). 
Tyto dva způsoby, jak rozumět „znaku“ jako specifické relaci v různých variacích, z velké části určují založení jakékoliv epistemologie, která samu sebe chápe jako postavenou na úhelném kamenu reprezentace, zprostředkování nebo v širokém slova smyslu na medializaci. Proto je vůdčí myšlenkou tohoto textu jistý normativní ideál, že pokud chce někdo brát sémiotické a sémiologické koncepty „vážně“, nebo je dokonce aplikovat v rámci nějakého výzkumu, měl by se i v př́padě svébytné interpretace nejprve alespoň v základu zaobírat samotnými texty těchto autorů. Zejména pak príimout jistý „,filologický“ fakt (jistou etickou interpretační maximu), že se nejedná o jednolité a jednoduché představy, ale komplexní a myšlenkově bohatá díla.

Společným př́iznakem mnohých z hlediska sémiotiky zavádějících sociálně-mediálních studií, kterým se konkrétně budu věnovat v závěru, je, že na původní texty často neodkazují bud' vůbec (viz např. Mitoseková 2009; Chromý 2014), nebo odkazují na přehledové, sekundární až terciární zdroje ${ }^{3}$. V jiných př́ípadech se pak sdělované postuláty o sémiotice oproti původním textům výrazně nepřesně redukují a vysvětlují mimo kontext, intence, koherenci a konzistenci původního textu (jako např. Jirák, Köpplová 2003 nebo Černý, Holeš 2004), ${ }^{4}$ a to i přesto, že se často tito autoři prezentují právě jako odborníci na komunikaci. Ze zcela formálního hlediska viděno, pokud se vůbec na Saussura a Peirce odkazuje, činí se tak mnohdy matoucím způsobem, tj. nikoliv podle zavedených stránkování závazných kritických edic. Je tedy prvně třeba vysvětlit, co se zde těmito edicemi míní.

\section{Saussure: Kurs obecné lingvistiky, rukopisy a komentáře}

V ideálním př́ípadě, pokud chce sociální či humanitní badatel přiměřeně porozumět Saussurovým východiskům, je třeba pracovat minimálně se samotným textem Kursu obecné lingvistiky (Cours de linguistique générale, dále CLG, př́padně Kurs), který je z principu fragmentární (jedná se o zapsané přednášky Saussurových studentů). Práce s CLG tak nutně znamená jednak vybudování interpretační perspektivy ${ }^{5}$ a zároveň práci s kritickým, sémioticky zasvěceným, minuciózním komentářem Tullia de Maura (1932-2017), dále pak se Saussurovými poznámkami ke Kursu, jeho rukopisy a v neposlední řadě s komentující sekundární literaturou (tj. komentáŕi pracujícími př́mo s prameny, jako jsou např. Thibault 1997; Parret 1976; Harris 1987; Harris 1990 ad.). Prvně lze pak poměrně přesně odlišit (přinejmenším v některých místech), co je Saussurovými myšlenkami a co prací editorů. Lze se tak částečně vyhnout některým zjednodušujícím představám ohledně jeho práce. Obrat k základnímu textu tak umožňuje relevantněji zhodnotit postavení Saussurových myšlenek v rámci

3 Př́značným je zde nap̌r. text Média a společnost (Jirák, Köpplová 2003: 135). Autoři zde hovoří o Peircově pojetí znaku (jak si ukážeme níže, velmi zavádějícím způsobem), avšak na Peircovy texty se neodkazuje.

$4 \quad$ Z prezentace obecného určení znaku v těchto textech (např. Jirák, Köpplová 2003: 134) často zavádějícím způsobem plyne zcela základní omyl, že sémiotika a sémiologie je totéž (viz Jirák, Köpplová 2003: 136).

5 Tedy jak vlastně CLG číst - zda (pokud to záměrně přeženeme) spíše jako formu méně souvislých poznámek, nebo jako vybudovaný systém pojmů. 
dalších interpretací, zejména ve vztahu k volnějšímu nebo posunutému zacházení se sémiologickými koncepty v rámci tzv. strukturalismu, který měl nepochybně dalekosáhlý dopad na sociálně vědní myšlení 20 . století. ${ }^{6}$

\section{Peirce: Sebrané spisy, chronologická edice a hodnocení Peircova díla}

Situace je neméně komplikovaná u Peirce. Zde má badatel k dispozici dva olbř́mí editorské projekty. Jsou jimi jednak Collected Papers (Peirce 1931-1958; dále CP), které jsou vhodné k základní orientaci v Peircově díle. Dále pak chronologická edice Peircových spisů - Peirce Edition Project (Peirce 1980). Dalším důležitým zdrojem pro přesnější pochopení sémiotiky jsou Peircovy nepublikované rukopisy. V neposlední řadě je zde řada několika systematických výborů, jako jsou napřr. Essential Peirce (Peirce 1992; EP1, EP2).?

Stejně tak jako u Saussura je třeba u Peirce rozlišovat mezi sekundárními komentáŕi, přičemž i mezi nimi lze sledovat podstatné posuny spojené právě s vydáváním a (dodnes pokračujícím) etablováním Peircova myšlenkového odkazu. Mezi základní sekundární texty tak patří jednoznačně komentáře Peircových editorů a první generace badatelů nad Peircovými spisy (srov. např. Burks, Weiss 1945; Ketner, Kloesel 1986 ad.). Dále jsou to důležité pokusy Peirce zasadit do debat současné filosofie a jeho filosofické perspektivy „historiograficky“ systematizovat (jako např. Hartshorne 1984; Apel 1973; Apel 1975; Anderson, Hausman 2012 ad.). Nakonec jsou $\mathrm{k}$ dispozici chronologicky vydanými texty poučené interpretace Peircovy sémiotiky (především Short 2007). Z hlediska sociálních věd je zde př́iznačný dopad Peircových myšlenek a jejich volnější aplikace zejména skrze pragmatistický proud v sociologii a sociální filosofii, jehož dědicem je do jisté míry Jürgen Habermas (srov. Aboulafia et al. 2012) a zcela evidentně např. Hans Joas (viz např. Joas 1993; Bertilsson 2009).

Díky postupnému vypracovávání interpretačních perspektiv byla Peircova sémiotika v mnoha př́padech značně zkreslena. At' už z důvodu náročnosti a komplexnosti jeho díla ${ }^{8}$, nebo z důvodu volného využití některých Peircových myšlenek k vlastním badatelským záměrům jeho interpretů. $\mathrm{V}$ tomto směru trojici autorit tvoří zejména Umberto Eco, který se s tímto dílem vyrovnával celý život a je autorem jednak mnoha brilantních postřehů, ale také mnoha podstatných a rozšířených omylü9, které sám na konci své kariéry značně reviduje (srov. Eco 2011; Švantner 2014a). Dalším slavným popularizátorem Peircova odkazu a sémiotiky byl Roman Jakobson, jehož zásluhou byla zpopularizována triáda ikon-indexsymbol, díky čemuž je Peircova sémiotika často redukována pouze na tuto triádu. ${ }^{10}$ Třetí

$6 \quad$ Mj. skrze osobnosti jako byli Michel Foucault (2000), Pierre Bourdieu (1998) či Claude Lévi-Strauss (2009).

7 A nakonec spisy věnované konkrétním oborům, jako jsou např. New Elements of Mathematics (Peirce 1976; NEM).

8 A Peircovým obskurním a někdy nekonzistentním vyjadřováním.

9 Př́značná je zde debata, která se vedla o Ecově Teorii sémiotiky (Eco 2009) a relevantnosti a přesnosti jeho intepretací Peirce a nařčení Peirce z domnělého ,ikonismu“ (k debatě viz Polidoro 2015); ke kritice Ecovy interpretace Peirce srov. např. Colapietro (1987); Švantner (2014a); (Proni 2015).

10 Je otázkou, nakolik jde o inspiraci a nakolik lze považovat Jakobsonovo čtení Peirce za (ne)přesnou interpretaci (srov. Gvoždiak 2012: 19, 54). 
významnou autoritou je $\mathrm{v}$ tomto směru Jacques Derrida, který Peirce, vášnivého čtenáře Kanta, interpretuje kvazi-saussurovským slovníkem jako „dekonstruktivistu transcendentálního označovaného“, a je spolu s Ecem autorem myšlenky radikálně nekonečné sémiosis, která je Peircovi často podsouvána. ${ }^{11}$

Pointou zde není to, že každý sociálněvědní teoretik by měl být sémiotikem nebo historikem sémiotiky, ale pouze to, že znalost historického kontextu a základních myšlenek pramenů může mnohá konceptuální přehlédnutí odstranit. Zejména pak v př́padech, kdy se tato přehlédnutí mají stát základem právě pro sémioticky konstruovanou teorii logiky a dynamiky sociálních a kulturních fenoménů.

\section{Některé interpretační omyly: exemplární enumerace}

Na základě výše uvedeného můžeme rozlišit několik vžitých omylů, které vznikly při adaptaci základních sémiotických konceptů mimo obory se sémiotikou tradičně spojené (jako jsou lingvistika, rétorika a logika). Jak uvidíme níže, následně se do velké míry tato zkreslení kanonizovala a stala se, zejména $\mathrm{v}$ českém prostředí, trendy. ${ }^{12}$ Tyto zavádějící tendence lze shrnout následovně. $V$ prŕípadě de Saussurova konceptuálního rámce jde především o:

a) Zcela mylnou představu, že znak se skládá jednak z „vyřčeného slova“ (označující), tedy nějakého konkrétně artikulovaného zvuku, a toho, co označuje mimo jazyk, nějaké „fyzické části“ (označované). Jinými slovy např. představa, že vyřčené slovo „kočka“ označuje kočku jakožto zvíře.

b) Podobně zavádějící je rozšířená a nepřesná subjektivistická interpretace označujícího jako „vyřčeného slova“ a označovaného jako „,o si pod tím kdo představi““.

V př́ípadě Peirce jde zejména o:

a) Zmíněné připsání myšlenky radikálně nekonečné sémiosis, vedoucí $\mathrm{k}$ řazení Peirce mezi „mentalisty“ či „nominalisty“. V di̊sledku by se tak jednalo o perspektivu opřenou o tezi, že skrze znaky poznáváme pouze znaky samé. Tato kvazi-nominalistická perspektiva jde přesně proti Peircovým intencím. $V$ rámci historie sociálních věd se tak

11 Ke kritice Derridovy interpretace Peirce představené ve spisu O gramatologii (Derrida 1999) srov. (Short 2007: 45; Švantner 2014a). Je pravdou, že Peirce hovoří o neomezenosti sémiosis (CP 2.203), nicméně pouze co do principu: interpretant (tj. obsah formální kvazi-mysli determinovaný působením znaku) jednoho znaku se může stát objektem pro další znak a tak dále ad infinitum. Je však třeba druhým dechem dodat, že Peirce $\mathrm{z}$ tohoto faktu nevyvozuje důsledky pro pravdivost a relevanci interpretací. Ta se u Peirce týká především otázky jednak toho, nakolik je správná forma našeho usuzování, a na straně druhé s tímto spojeného faktu, nakolik interpretant znaku postihuje v rámci usuzování representovaný objekt (klíčovou otázkou Peircova pragmaticismu je, jak určit přijatelnou třídu indexů pro vědecký výzkum). Nemáme zde prostor pro ucelený výklad Peircovy teorie pravdy, zastáváme zde názor Christophera Hookwaye, že Peircova perspektiva je originální (sémiotickou) kombinací adekvační teorie pravdy s ohledem na konzistenci forem usuzování (srov. Hookway 2002). Viz níže rozbor Peircovy sémiotické teorie.

12 Stejně nešt’astné omyly, které lze nalézt v českých mediálních studiích, prezentuje v zahraničí např. Bignell (2002: 5). 
objevuje automatické a chybné řazení Peirce spolu s jeho pojetím sémiotiky do velké rodiny relativistického postmodernismu nebo dokonce sociálního konstruktivismu (srov. Marková 2003: 39). S touto zavádějící perspektivou se pojí české označení „semióza“, pod nějž se někdy mylně zahrnuje Peircova a Saussurova perspektiva jako splývající. Výrazem tohoto omylu, který níže ukážeme, je představa, že Peircovo pojetí znaku (jako representamen) „zhruba odpovídá Saussurově označujícímu“ (Černý, Holeš 2004: 45). Neodpovídá mu ani „zhruba“.

b) Redukce sémiotiky na druhou triádu Peircovy středně/pozdní znakové klasifikace (ikon, index, symbol).

c) Představa Peircova pojetí symbolu jako doslovně arbitrárního nebo konvenčního znaku (Černý, Holeš 2004: 27). Uved’me předběžně, že pro Peirce je symbol zákonem denotujícím to, co tomuto zákonu podléhá. Podle Peirce i fenomén jako př́rodní zákon je symbolem, kde lze o čistě sociální konvenci hovořit stěží.

Další omyly se týkají slučování obou autorů, tedy především mínění, že:

e) Sémiotika a sémiologie jsou v podstatě to samé s tím rozdílem, že Peirce „přidává“ $\mathrm{k}$ označujícímu a označovanému navíc objekt. ${ }^{13} \mathrm{~S}$ touto představou je někdy spojený zcela vágní termín „sémiotické analýzy“. Ta se někdy prezentuje jako jednoduché, subjektivistické a naivně schematické nasazení zde zmíněných omylů (ergo redukcí odlišných sémiologických a sémiotických východisek autorů) na vcelku banální a zjevné věci. Pokud to přeženeme, máme zde na mysli vulgární způsoby toho, čemu se ř́íká sémiotická analýza na způsob: „červená značí lásku“ a „znaky jsou všude kolem nás“.

Je třeba dodat, že tyto omyly existují jak v této analytické formě, tak se různě syntetizují, „komunikují mezi sebou“ a generují další řady zkreslení. Popíšeme je konkrétně v závěrečné části textu. Prvně je třeba jít ad fontes a poukázat na vybraná locis základních textů, která směšování sémiotických a sémiologických paradigmat podstatně ztěžují.

\section{Prípad Saussure}

Pokud naši interpretaci omezíme pouze na často dezinterpretované teoretické postoje, pak se naše selektivní čtení CLG zaměří zejména na vybrané pasáže z první a druhé části. Kritériem výběru je zde široké uplatnění těchto teoretických modelů $\mathrm{v}$ sociálních vědách a omyly s těmito interpretacemi spojené. Jedná se prvně o téma pojetí jazyka jako systému (později překřtěného na strukturu) a otázku systému vůbec. ${ }^{14} \mathrm{Je}$ třeba avizovat, že vzhledem $\mathrm{k}$ rozsahu textu a záměrům $\mathrm{v}$ závěru představené kritiky zde vynecháváme některá témata podstatná jak pro samotný CLG, tak pro obecnou epistemologii sociálních věd. Jde o témata syntagmatic-

13 Viz níže konkrétní analýzy českých textů.

14 Kde Saussurova perspektiva tvoří protiváhu k jiným systémovým teoriím etablovaných v sociálně vědní tradici, tradičně k Parsonsově a Luhmannově perspektivě (saussurovsky chápaná struktura nemá vnitřek ani vnějšek, jejichž dialektický vztah je klíčový mj. pro sociologickou systémovou teorii). Srov. zde otázku vnitřních a vnějších aspektů systému (CLG, 43). 
kých a paradigmatických vztahů, otázku hodnoty znaku či problém synchronní a diachronní analýzy. Klíčovým východiskem je pro nás především Saussurova nespokojenost s tím, že lingvistika postrádá základní a obecné principy svého fungování. Ty má zajistit obecná teorie znaku, již Saussure nazval sémiologií (CLG: § 3). Ta nás bude (mj. pro své určení jako vědy studující život znaků ve společnosti) zajímat nejvíce.

Vedle otázky systému/struktury, jež je v CLG určena čistě relačně a diferenčně, je často tematizované Saussurovo určení znaku jako dyadické relace označujícího a označovaného, jejichž vztah je stanovený arbitrárně, tj. nemotivovaně co do vztahu označujícího a označovaného, a zároveň konvenčně, tj. vztah dvou stránek znaku je vymezen systémem daného jazyka.

Další z primárních otázek, která se v CLG objevuje, je vztah mezi jazykem/systémem a jeho konkrétními realizacemi. Jinými slovy vztah mezi tím, co Saussure označuje (i) řečí jakožto obecnou a mnohovrstevnatě manifestovanou lidskou schopností (langage); (ii) jazykem jakožto specifickým systémem (langue), který je hlavním cílem lingvistické analýzy; a (iii) mluvou jakožto realizací jazykového systému v konkrétních, individuálních mluvních situacích (parole).

Předběžně poznamenejme, že vzhledem k výše uvedenému je Saussure nikoliv homogenní autor, a pokud formulaci záměrně přeženeme, nemůžeme si být nikdy cele jisti, jak některým jeho východiskům rozumět ${ }^{15}$ (přičemž tato skeptická maxima platí rovnoměrně u Peircova díla a taǩ̌ka ji nenalezneme v níže kritizovaných textech). Tato metodologická nejistota však neznamená, že nelze jisté flagrantně nepřesné vývody analyzované v závěru tohoto textu odmítnout jako nepodložené nebo zavádějící.

\section{Epoché: otázka interpretační perspektivy}

Z tohoto důvodu je třeba říci, že stejně jako je několik historických linií výkladu zrození Saussurova Kursu, je i několik výkladových linií, jak lze celek CLG interpretovat. Pro účely tohoto textu zde rozsáhlé myšlenkové dědictví Kursu velmi omezíme a budeme se věnovat pouze vybraným pasážím důležitým pro kritické účely. Budeme tak primárně sledovat rozšírenou linii čtení Saussura jako v podstatě specifického racionalisty ${ }^{16}$, pro kterého je individuum podř́zeno takřka cele „kvazi-statickému“ systému jazyka sestaveného z netělesných (disembodied) relací (srov. Klinkenberg 2014: 22). Tento př́stup je do velké míry na jedné straně velice funkční a plodný, jak svědčí přejímání myšlenek CLG v rámci francouzského strukturalismu. Druhým dechem dodejme, že i v rámci (lingvistického a sociálněvědního) strukturalismu se recepce CLG často podstatně odlišují. ${ }^{17}$

15 Krampen podotýká, že touha po autorsky autentické interpretaci CLG se někdy podobá snaze biblistů rozpoznat autentické výroky Ježíše (Krampen 1987: 62).

16 Viz zejména Hutton, Pable (2015: 2); srov. Normand (2006: 92-93). Rád bych zde, v suterénu poznámky pod čarou, zmínil, že tuto interpretační perspektivu osobně nesdílím. Kritické poznámky k této kanonizované perspektivě čtení Saussura nabízí Thibault (1997); Stawarska (2015).

17 Zejména podíváme-li se na recepci CLG v rámci strukturalistické jazykovědy (např. v textech Emile Benvenista nebo raného Rolanda Barthese (srov. Raffaele 1992), nebo na volné zacházení 
Pokud toto specifické prisma pro začátek hrubě shrneme, tak jde o to, že Saussure vidí jazykový systém jako striktně formální a autonomní. Což znamená, že v druhém plánu Saussure odděluje individuum od společnosti, stejně jako jazyk-systém od dalších nejazykových znakových systémů, pro které je však primárním modelujícím systémem (srov. Lotman 1991). Společnost (jakožto komunita mluvčích) je z této perspektivy především donucovací anonymní totalitou, která je vůči individuu vnější. Řečová praxe individua je oddělená nebo vnější jazykovému systému, který je uzavřený a statický a v podstatě nemá žádný kontakt s tím, co filosofové nazývají svět (srov. Thibault 1997: xvii-xviii; Ogden-Richards 1932).

\section{Zákony jazyka jako zrcadlo zákonitostí sémiologie}

Z této dílčí interpretační perspektivy (Saussura jako „racionalisty“) lze dovodit, že Saussurův projekt má být nakonec konstrukcí vědy, která hledá ${ }^{18}$ obecné zákonitosti jazykového systému (langue), který takřka cele determinuje možné realizace v konkrétní mluvě (parole) a snad dokonce může být modelem pro vysvětlení toho, jak funguje řeč (langage) vůbec ve své obecnosti a různých manifestacích. ${ }^{19}$

Konkrétním předmětem lingvistického výzkumu má být „společenský produkt uložený v mozku každého jednotlivce, to jest jazyk“ (CLG: 44), lišící se podle různých jazykových skupin. Tento společenský produkt pak lze pochopitelně zkoumat v jeho dvou základních projevech: v psané a mluvené formě. Je třeba dodat, že Saussurův projekt v tomto směru s sebou nese (zejména pro pozdější interprety) podstatné schizma mezi důrazem na kodifikovanou stránku jazyka, jakou mohou být např. gramatické systémy živých i mrtvých jazyků (jejichž „mluvené slovo“v „běžné mluvě“ v podstatě neexistuje, viz CLG: 31), a na straně druhé jeho důraz na to, že lingvistika se má vymanit z diktátu písma a jejím předmětem je slovo mluvené a nelze si ,plést jazyk s jeho pravopisem“ (CLG: 45). Je třeba říci, že pro pozdější prosazení,

se Saussurovými myšlenkami např. v textu jako jsou Slova a věci Michela Foucaulta nebo Strukturální antropologie Clauda-Lévi Strausse (srov. zde Ardener 2013). Je třeba dodat, že stejně jako neexistuje ,jediný Saussure“, stejně tak neexistuje ,jediný strukturalismus“ v rámci tzv. strukturalistických škol (srov. Hoskovec 2008). Lze říci, že tato na jedné straně funkční a na straně druhé reduktivní pojetí se stávají kánonem a Saussurovi jsou přisuzována stanoviska, která zřejmě vůbec nezastával - jako je tomu u slavné ,poststrukturalistické“ kritiky písma u Jacquese Derridy v Gramatologii nebo tzv. lingvistických postulátů u Gillese Deleuze a Félixe Guattariho v Tisíci plošinách, nebo na druhé straně oceánu u Noama Chomskyho (srov. Eniko 2006). Pro kritiku Chomského pojetí dějin lingvistiky viz zejména Aarsleff (1982: 116); kritické čtení Derridovy interpretace prredstavuje Daylight (2011).

18 A v jistém ohledu stanovuje - at’ už ve smyslu systematickém, totiž že chce postihnout zákony nebo principy, na jejichž základě může jazyk vůbec fungovat; nebo ve smyslu „historickém“: Saussurem v Kursu představená pravidla se později stávají nap̌r. pro mnohé strukturalistické perspektivy, pokud ne „zákony“, tak přinejmenším axiomatickými postuláty (srov. Krampen 1987: 64); pro analýzu Saussurovy pozice v rámci dějin lingvistiky viz Amsterdamska (1987).

19 Jazyk je pozdějším strukturalismem často chápán v sociální praxi jako dvojitě integrovaný: jako nástroj a zároveň jako model (srov. CLG: 33; Krampen 1987: 63). Lingvistika tedy nemá být nutně omezena pouze na výzkum kodifikované formy řeči at’ už ve formě pravidel používání jazyka, nebo rétorických tropů. 
zejména $\mathrm{v}$ rámci tzv. francouzského strukturalismu 60 . let, je tento problém do velké míry redukován. Text i mluva ve svých empirických variacích podléhají obecnému systému jazyka a Saussurovo důsledné oddělování těchto dvou složek se tak z tohoto hlediska jeví jako bud' redundantní, nebo jako dané historickými okolnostmi. ${ }^{20}$ Diktum hledání zákonitostí vede pak k velkému projektu lingvistiky jakožto vědy stanovující jednak popis a rekonstrukci všech jazyků s jejich historií, jednak stanovení obecných zákonitostí, a to jak v jejich obecnosti, tak ve specifickém působení v konkrétních jazycích. ${ }^{21} \mathrm{~V}$ CLG tak nalezneme jak podněty pro (re) konstrukci abstraktního systému jazyka, tak jistý ohled na konkrétní sociolingvistickou praxi, která však nakonec obecnému systému podléhá. ${ }^{22}$

Posledním úkolem lingvistiky je souběžně vymezit samu sebe na základě vnějšího principu. Pokud totiž definujeme lingvistiku jako vědu o jazyku, okamžitě otevíráme nutně obecnou otázku, co je to řeč nebo jazyk. Již na začátku svých úvah definuje Saussure řeč jednak jako striktně psychologickou a dále jako sociální fakt a lingvistiku tak nepřekvapivě esenciálně spojenou se sociologií a sociální psychologií. Vidíme, že již v začátku se objevuje postulát lingvistiky zkoumající jazyk bez nánosu jakéhokoliv biologismu nebo lingvistiky vztažené k fyziologii, ${ }^{23}$ což se ukáže níže jako důležité u Saussurova pojetí znaku. Jak Saussure uvádí:

Jiné vědy pracují s předměty danými předem, které lze nazírat z ri̊zných hledisek; v naší oblasti nic podobného není. Někdo řekne francouzské slovo $n u$ („nahý“): povrchního pozorovatele to bude svádět $\mathrm{k}$ tomu, aby $\mathrm{v}$ něm viděl konkrétní jazykový př̀edmět. Avšak pozornější zkoumání v něm odhalí postupně tři či čtyři zcela různé věci podle toho, jakým způsobem se nazírá: jako zvuk, jako výraz určité myšlenky, jako ekvivalent latinského nudum atd. Předmět ani zdaleka nepředchází hledisku, a dalo by se říci, že je to právě hledisko, které vytváři předmět; nic nám ostatně předem neříká, že jeden ze způsobů nazírání dané otázky druhým předchází nebo nad nimi převažuje. (CLG: 23)

Saussurův následující komentář představuje základ toho, co se později nazve jako lingvistický strukturalismus, kde je systém jakožto formální jednotka analýzy v čase a prostoru udržován skrze „,̌isté diference“ nebo „velké jazykové antinomie“: jinými slovy skrze zakládající dialektický vztah dvou stránek jazyka působící jedna skrze druhou. V analýze tohoto lingvistického faktu však můžeme jít ještě hlouběji. V př́ípadě slova jsou zde jistě skrze hlasové orgány artikulované slabiky a zvuky vnímané uchem, nicméně jazyk nelze pouze takto

20 Jako je Saussurova kritika historické a komparativní lingvistiky, např. Franze Boppa či Jacoba Grimma (viz CLG: 46).

21 Tento obecný zájem lingvistiky je pak později tím, co je z velké části adoptováno konceptuálním rámcem strukturalistické sociální vědy.

22 Srov. CLG: pozn. 63: „Jazyk je soubor nutných konvencí přijatých společenským útvarem, který umožňuje používání schopnosti řeči u jednotlivců. Schopnost řeči je fakt od jazyka odlišný, jenž se však sám bez něj používat nemůže. Mluvou označujeme akt jednotlivce, jenž svou schopnost realizuje prostřednictvím společenské konvence, jíž je jazyk.“

23 Otázka přirozenosti jazyka aktuální v bádání 19. století se, stejně jako funkce hlasového ústrojí, jeví pro Saussura, který v tomto směru následuje amerického lingvistu Williama Dwighta Whitneyho (1827-1894), druhotnou až nepodstatnou viz (CLG: 26): ,jazyk je konvence a je lhostejné, jaká je povaha dohodnutého znaku“". 
„fyziologicky“ redukovat. Je evidentní, že kromě zvuku se přenáší i nějaké myšlenky. Tedy zvuk jako „komplexní akusticko-vokální jednotka tvoří s myšlenkou (...) komplexní fyziologickou a mentální jednotku“ (CLG: 24).

Zde je podstatné upozornit, že CLG půjde v myšlence abstraktnosti a striktní psychologizace znaku dále. Tedy že na tomto místě CLG jde o analytický mezikrok a že nelze ztotožnit myšlenku mentální dyadické relace označujícího a označovaného s představou vyřčený zvuk/myšlenka. Jak ještě uvidíme - a CLG to jasně ř́íká -, znak jakožto formální jednotka sémiologické analýzy bezpochyby není vztah mezi vyřčeným slovem a myšlenkou, a tím spíše ne mezi slovem a věcí.

Něco jiného je tedy jazyk (langue), který je oproti řeči celkem a zároveň principem klasifikace: „Jakmile mu mezi fakty řeči přidělíme místo, zavedeme přirozený řád do souboru, který se žádné jiné klasifikaci nepodvoluje“ (CLG: 25). Pro člověka tak není přirozená mluvená řeč, ale schopnost vytvářet jazyk, tj. jednak „systém zřetelných znaků odpovídající zréetelným idejím“ (CLG: 26) 24 , a jednak nástroj vytvářený a poskytovaný společenstvím, který dodává jednotu řeči. Jazyk je tak jasně vymezený objekt zkoumání v obsáhlém a různorodém prostoru řeči a jakožto systém jej lze zkoumat zcela odděleně od jeho variabilních projevů v mluvě. ${ }^{25}$ Jeho základním určením je sémiologická funkce, totiž vymezení asociativního spojení označujícího a označovaného, jinými slovy auditivního obrazu (nebo akustického nebo verbálního obrazu) a konceptu. ${ }^{26}$

Výchozí perspektivou Saussurova pozorováníi ${ }^{27}$ je fakt, že centrem jazyka je mozek a Saussurem tematizovaný znak je bytostně mentální jednotkou spojující:

a) Fakta vědomí, jinými slovy koncepty (,,pojmy“).

b) Reprezentace jazykových znaků, akustické obrazy; jinými slovy mentální obrazy toho, jak bude znak vokálně artikulován; ještě jinými slovy - jedná se o koncepty (,pojmy“) artikulovaného zvuku.

V procesu komunikace, tj. v momentě, kdy se systém, jako je jazyk, realizuje v mluvě, daný pojem vyvolá v mozku komunikujícího odpovídající (tj. v rámci daného jazyka) akustický obraz. Tento (podle Saussura „,̌istě“) psychický jev je následován „fyziologickým“ procesem, kdy mozek předává fonačním orgánům „impuls odpovídající tomuto obrazu“ (CLG: 28). Zvuk se pak šiří fyzickým prostorem k druhému komunikujícímu a proces zde probíhá v obráceném pořadí od fyzického šírení zvukových vln $\mathrm{k}$ uchu a fyziologicky pak

24 Tedy nikoliv systém snoubící slova a věci); v orig. ,,[...] un système de signes distincts correspondant à des idées dicstinctes".

25 Pro tento často kritizovaný postulát uvádí Saussure následující argument: „Mrtvými jazyky nemluvíme, ale jejich jazykový organismus si můžeme osvojit velmi snadno“ (CLG: 31).

26 Srov. CLG: 32: „Zatímco řeč je různorodá, je takto vymezený jazyk stejnorodý: je to systém znaků, v němž to nejpodstatnější je jednota smyslu a akustického obrazu a v němž obě části znaku jsou ve stejné míře čistě psychické povahy“" (srov. CLG: 166). Je třeba dodat, že se zde nesnažíme rozřešit $\mathrm{v}$ dějinách sémiotiky diskutovaný problém primátu lingvistiky nad sémiologií a vice versa (srov. Krampen 1987: 64).

27 Srov. CLG: pozn. 68 a interpretaci některých saussurovských perspektiv jakožto svébytného positivismu. Pro kritiku této predstavy viz Thibault (2013: 30). 
k mozku a odtud nakonec k psychickému spojení akustického obrazu s pojmem. Podstatnou věcí, která je opomíjena, je Saussurova poznámka, že nejdůležitější je si uvědomit, ,,̌ee akustický obraz se se zvukem samým neshoduje a že je psychický jako pojem, který je k němu asociován " (CLG: 29, kurzíva MŠ; srov. CLG: 97-100).

Tedy jasnou pointou je, že oproti představám některých interpretů, na které si poukážeme níže, znak jakožto jednotka „,̌istého“ sémiologického výzkumu nenese nic „fyzického“.

\section{Epistemologické důsledky}

Pokud tedy existuje znak, který je dyadickou relací mezi zvukem a představou, nebo dokonce mezi zvukem a objektem, existuje pouze $\mathrm{v}$ jiných teoretických konceptech a nemá se Saussurovou perspektivou nic společného. Je tedy na pováženou, nakolik brát v potaz výše odkázanou kritiku (mj. Klinkenberg či Ogden-Richards), že Saussurova perspektiva je neztělesněná nebo že postrádá „referent“. Je zde třeba zásadně doplnit, že se nejedná o referent ve smyslu Peircova objektu, ale o mimosystémové motivace, které jsou pouze zdánlivě systémové (jako jsou v prŕpadě lingvistiky onomatopoia nebo to, čemu Saussure rríká symbolické znaky). Vztah mezi těmito dvěma jednotkami (označujícím a označovaným) je arbitrární, jinými slovy nemotivovaný, tedy svazek mezi sledem hlásek s-e-s-t-r-a nemá s konceptem/ představou „sestry“ jakýkoliv vnitřní, přirozený nebo jinak motivovaný svazek než ten, který určuje systém konkrétního jazyka (viz CLG: 100). Jinými slovy je tento vztah rozhodnutý jazykovou konvencí, tedy arbitrární a opět se nepojí s žádnou mimojazykovou referencí (je konvenčně stanovenou relací dvou mentálních obsahů).

Je třeba doplnit, že chápat termín „symbol“ jako v tomto smyslu konvenčně stanovený znak je nepřesné. Jak u Peirce, jak jsme naznačili výše a ukážeme si níže, tak i u Saussura, který symbol pojímá v tomto místě Kursu jako kvazi-znak, „zanesený“ zmíněnou „referencíc28. Jak uvádí Saussure:

V povaze symbolu je, že nikdy není zcela arbitrární: není totiž prázdný, je v něm zbytek přirozeného svazku mezi označujícím a označovaným. Symbol spravedlnosti, váhy, by nebylo možné nahradit jiným, např́klad vozem. (CLG: 101)

28 Je třeba dodat (a za toto upozornění děkuji Vítu Gvoždiakovi), že v CLG: 348 v poznámkách ke Kursu, v jistém Saussurově rukopise věnovaném Nibelungům lze nalézt i zcela protichůdné tvrzení, totiž že sémiologie se zabývá symboly (resp. že „všechny [symboly] jsou součástí sémiologie“). Domnívám se však, že Saussure zde (jak sám uvádí) pojetí symbolu precizuje, což neodpovídá cele tomu, jak o symbolech mluví ve výše odkazované pasáži Kursu. Tedy „symbol“ (Saussure uvádí př́klad legend - ve smyslu narativního žánru -, které jsou „plné symbolư“) se může stát objektem výzkumu sémiologie, pokud se v něm rozpoznají strukturní zákonitosti. Jak Saussure dodává: „A právě v tomto obecném duchu budeme přistupovat $\mathrm{k}$ legendě, protože každá $\mathrm{z}$ postav je symbolem, u něhož lze postřehnout variování [...] ve a) jménu, b) postavení vůči druhým, c) povaze, d) funkci, činech [...]. “Přičemž v této pasáži lze postřehnout to, co bude později zajímat kulturologický strukturalismus - přenesení mezi různými - jak říká Saussure - společenskými masami. Tedy př́nos nového prvku do systému, který mění jeho vnitřní pravidla („mění celé drama“). Pokud to shrneme, sémiologie nezkoumá symboly ve vlastním smyslu, ale zkoumá na symbolech to, co je znakem. Je třeba zmínit, že např. Derrida v Grammatologii obrací tuto Saussurovu perspektivu 
V rámci Saussurovy analýzy (pokud je pravdou, že jazykový systém je vymezený jako struktura diferujících prvků) je tak symbolu vyhrazeno místo mimo sémiologickou analýzu, stejně jako zmíněným onomatopoickým výrazům (srov. CLG: 102): na základě tohoto „nečistého“ přimísení (historického a kulturního nánosu, typu „zvykových znakư“) nelze na základě symbolů vystavět jasnou systémovou a formální analýzu, která je cílem sémiologie. Jinými slovy na „symbolu“ je možné analyzovat pouze jeho sémiologické prvky.

Jak Saussure uzavírá, a je $\mathrm{v}$ tomto naprosto radikálně následován později např. $\mathrm{L}$. Hjelmslevem, a zůstává tak v tomto nepochopen pro některá sociální studia: „věda o jazyce se bez jiných prvků řeči může nejenom obejít, ba není možná, jsou-li tyto jiné prvky do ní primíseny“ (CLG: 32).

Výše popsané schéma je zdrojem revolučního prosazení strukturalismu a jeho primátu induktivně/deduktivních metod $\mathrm{v}$ sociálních vědách, jež podle této perspektivy mají zkoumat především systém, který takřka beze zbytku determinuje konkrétní procesy. Analyzovaný znak jakožto dyadická relace je v této perspektivě (je arbitrárním svazkem dvou ,ideji““) stanovený pouze transcendentálně, $\mathrm{tj} . \mathrm{v}$ tomto smyslu se váže pouze $\mathrm{k}$ danému systému jako jeho diferenčně organizující prvek. Pokud by byl vázán jakožto relace „ontologicky“, tj. označoval by „věci“, celá strukturální (nebo sémiologická) analýza by se nejenomže rozpadla do nesoudržného univerza, ale nebyla by obecná, tj. byla by nefunkční a tedy nesmyslná. Ukázali jsme, proč je z hlediska CLG mylné se domnívat, že znak je směsí fyzického slova a věci, stejně jako fyzického slova a představy - sémiologie je zde stejně formální vědou, jako lingvistika, a potencionální výzkum se tak odehrává nikoliv v analýze fyzických realizací znaků, ale systémů, které je uvádějí do vztahů.

\section{Charles Sanders Peirce}

Stejně jako je obtížné shrnout často protichůdná tvrzení obsažená v CLG, je téměř nemožné na několika stránkách shrnout Peircovu sémiotiku. Omezíme se zde opět pouze na témata pojednávaná $\mathrm{v}$ textech, které $\mathrm{v}$ závěru budou předmětem kritiky. Prvně zopakujme Shortovu kritickou poznámku, která vyjadřuje do velké míry raison d’etre tohoto pojednání:

Kontinentální spisovatelé, kteří přistupují k Peircovi z perspektivy Saussurovy sémiologie, systematicky dezinterpretují jeho sémiotiku. Zavádějící spojování Saussurem předpokládaného konvencionalismu s - z kontextu vytrženými - pasážemi Peircovy pozdní sémiotiky vedlo ke zrodu hybrida extrémního relativismu a irealismu - ke zrodu moderní sofistiky, kterou by Saussure

a „stávání se symbolem znaku“ bere jako klíčovou vlastnost obecného znaku a obskurně tuto perspektivu přisuzuje Peircovi. Saussure podle Derridy staví pojem arbitrárního znaku (označující plus označované) proti symbolu (písmo jako reprezentace, obraz, znázornění jazyka). Derrida pak Saussurovi vytýká, že nepochopil to, že není takto pojatého znaku, ale že znak je bytostné stávání-se-znakem symbolu. Podle Derridy pak symbol u Peirce „hraje úlohu analogickou úloze znaku, kterou Saussure staví proti symbolu“ (Derrida 1999: 54-55), což je komplexní omyl, na který si ukážeme níže. Je třeba poznamenat, že samotný význam slova „symbol“ se mnohdy podstatně proměňuje, jeho stručnou historii a etymologii uvádí (Eco 2005: 14-17), srov. historickou genezi pojetí symbolu v antice in Charvát, Karl'a, Švantner (2015). 
i Peirce odmítli. Proto tyto spisy nepovažuji za formy čtení Peirce, ale za alternativy k jeho teorii. (Short 2007: xiii)

Jak si ukážeme konkrétně po tomto exkursu, tito teoretici vytvářející vzhledem k primárním textům neadekvátní syntézy mísící Saussurovu sémiologii a Peircovu sémiotiku se mj. rekrutují z řad českých mediálních studíi. Jak jsme podrobně ukázali výše, pro Saussura je znak jakožto dyadická relace dvou idejí (jakožto obsahů mysli) nutně nemotivovaný a stanovený daným jazykovým systémem, který není určen (motivován) mimo-lingvisticky či substanciálně, ale obsahuje pouze sady opozic. ${ }^{29}$

\section{Klíčové rozdíly mezi sémiologií a sémiotikou opřené o povahu znaku}

Pro Peirce prvně ,znak“ nese zcela jiný význam. Znak je pojímán jakožto ontologická triadická relace:

a) objektu (to, co determinuje znak jako representamen),

b) representamenu (to, co zprostředkovává tuto determinaci)

c) interpretantu (to, co toto zastupování „vyvolává“ v percipující mysli (srov. CP 2.228; CP 8.343)

Je tedy nutně ,motivovaný“, dokonce vždy specificky determinovaný svým objektem. Objekt může mít, oproti Saussurovi, kde se jedná o daným jazykovým systémem rozlišené jednotky vydělené z amorfní masy myšlenek a možných akustických obrazů, ontologicky různou povahu (bytí se skrze znaky vypovídá různými způsoby). Může jít napřr. jak:

a) o ,tuto dýmku“ ve smyslu dýmky, na kterou právě ukazuji (a její konkrétní existenci),

b) tak o jakoukoliv pomyslnou dýmku (dýmku Sherlocka Holmese),

c) o samotnou obecnou gramaticky správně utvořenou výpověd’ o dýmce atp.

Znakem můžou být také části výpovědi (o dýmce např.) stejně jako její celek, stejně jako je pro Peirce znakem i soubor propozic, který je argumentem. Nejpodstatnější rozdíl určující nepřevoditelnost analyzovaných paradigmat spočívá v následujícím: To, co pro Saussura bylo nevhodným ontologickým ,př̌imísením“ $\mathrm{k}$ transcendentální čistotě strukturální analýzy, je pro Peirce naopak východiskem pro to, jak znakům rozumět (je to jeden z důvodů, proč Peirce filosofii nazývá critical common-sensism nebo pragmaticismus (srov. CP 5. 438). Znaky jsou sice pro Peirce nutně ,ztělesněním“ triadické relace, zároveň je třeba dodat, že to neznamená, že by sémiotika jakožto závratná klasifikace všech možných znaků byla nějak „materialistická“" a nebyla aplikovatelná i na zcela abstraktní fenomény; je tomu právě naopak. Nelze tak ani říci, že by Peircova sémiotika Saussurovu sémiologii jako celek zahrnovala.

Jak jsme ukázali výše, Saussurův teoretický model, ač ovlivnil i široké pole jiných odvětví vědy, je primárně spojen s lingvistikou a je konstruován především pro její potřeby

29 Jak uvádí Vít Gvoždiak (2012: 52), „Peircovu sémiotiku - na rozdíl od evropské sémiologie - je vhodné chápat nikoli jako psychologicky či sociologicky determinovanou disciplínu, nýbrž jako vědu o logice znakových vztahů. “Je však třeba doplnit, že Peircovy cíle jsou mnohem širší, mírííi nikoliv pouze $\mathrm{k}$ logice znakových vztahů, ale např. i k sémioticky pojaté kosmologii. 
a sémiologie je budována právě na jejích základech. Peirce však neklade proces vznikání znaků pouze do sféry lidského jazyka a jeho teorie jsou charakteristické nikoliv ,panlingvismem“ (jako lze označit některá strukturalistická východiska), ale „pansémiotismem“, totiž přesvědčením, že nejen lidské, ale celé universum je komponováno ze specifické relace mezi objektem toho, jak je zastupován něčím dalším, a determinací, kterou toto zastupování vyvolává v mysli recipienta, tedy interpretantem (srov. CP 4.539). Mysl je však míněna jako kvazi-formální, tedy nikoliv jako u Saussura psychologický pojem. ${ }^{30}$

Tedy zatímco pro Saussura je jazyk radikálně společensko-psychologickým fenoménem, pro Peirce, čtenáře mj. scholastické tradice a Kanta, je jazyk radikálně ontologickým fenoménem. To znamená, že jazyk je zde především k tomu, abychom jej pochopili především jako prostředníka $\mathrm{k}$ určení plausibilní vědecké metody a $\mathrm{v}$ komunitě badatelů $\mathrm{v}$ rámci nikdy nekončícího výzkumu se pak pokoušeli dospět $\mathrm{k}$ nejpravděpodobnějším úsudkům o světě (srov. CP 1.13). Tedy zatímco podle Saussura to, co proměňuje systémy znaků, jsou strukturální změny jazyka (odtud také možnost diachronního lingvistického výzkumu), pro Peirce je to, co determinuje akci a vznikání znaků (sémiosis), evolvující skutečnost ${ }^{31}$. Proměňuje se nejen to, jak se k věcem stavíme (systémy signifikace), ale i samotné „věci“ proměňují to, jak se k nim stavíme, jakým způsobem je reprezentujeme v širokém spletenci vztahů, který se sémiotika doslova pokouší rozmotat (srov. CP 1. 280).

Zde vidíme limity každé stručně aplikované sémiotiky - každý, kdo chce (strukturalistickým slovníkem) Peirce redukovat na ,ikonu, index, symbol“ jakožto typ vztahů označujícího a označovaného, stojí před ontologickou otázkou objektu a jeho statusu (srov. zavádějící interpretaci in Trampota, Vojtěchovská 2010: 119). U Peirce je totiž podmíněno to, co chápeme jako znak, ohledem, v jakém je to interpretováno. Což je na univerzální rovině ohled ke třem ontologickým (faneroskopickým) kategoriím: prvosti, druhosti a třet’osti, které lze podle Peirce pozorovat ${ }^{32} \mathrm{v}$ každém obsahu mysli. Tedy obecně: je zde ohled k ,bytí“ (jako čisté potenci) nějaké ,skutečnosti“ (akci) a komunikaci (nějaké artikulaci, zákonu a kontinuitě). Znak tedy není definovaný jako prvek vztažený ke všem ostatním prvkům systému jako u Saussura. Prvky znakové relace, která je jinak založena, jsou i zcela jinak kombinovány.

Bez objektů by tak (oproti Saussurovi) pro Peirce nebyly možné znaky, a tedy ani možná řeč či jazyk (přičemž stejně jako termín ,znak“ nelze ztotožnit ,jazyk“ u Peirce se

30 Pro Peirce je typem mysli, tedy typem nějakého sémiotického/sémiosického habitu, který získal povahu zákona, i např. protoplasma (srov. CP 7.515; Short 2007: 311).

31 Navíc jsou Peircovy názory na samotnou lingvistiku naprosto odlišné od těch Saussurových. Peircovo hodnocení lingvistiky patří do 19. století se všemi nešvary, které se Saussure snaží opustit (viz CP 1.250).

32 Viz CP 2.227: „Domnívám se, že jsem prokázal, že logika je v obecném smyslu jen jiným jménem pro sémiotiku, kvazinutné či formální učení o znacích. Tím, že říkám, že toto učení je ,kvazinutné či formální, míním to, že pozorujeme rysy známých znaků a že od takového pozorování jsme procesem, který přes vlastní výhrady nazvu ABSTRAKCÍ, vedeni k tvrzením, jaké musí být rysy všech znaků užívaných ,vědeckým' intelektem, tj. intelektem schopným učit se ze zkušenosti, kterážto tvrzení mohou být nepopiratelně mylná, a tudíž v jistém smyslu zdaleka ne nutná. Co se týče zmíněného procesu abstrakce, je sám jistým druhem pozorování.“ 
Saussurovým langue). Nelze se tedy domnívat, jak se často činí, že Peircova sémiotika je vlastně Saussurovou teorií s přidaným třetím členem - objektem). Slovy T. L. Shorta:

Pokud měl Saussure pravdu a systém arbitrární signifikace může být studován v abstrakci od svého partikulárního použití, přirozených znaků a dalších forem nearbitrární signifikace, pak se Peirce mýlí. Pokud měl však Peirce pravdu v tom, že jazyku může být porozuměno pouze v konkrétním kontextu jeho použití, v kooperaci s dalšími druhy znaků, pak se mýlil Saussure. Jeden systém nemůže být částí druhého, protože jsou v kontradikci. (Short 2007: 19-20)

Ikon, index, symbol a ti druzí

V závěru tohoto exkursu si vyjasněme kontext slavného dělení na ikon, index a symbol. ${ }^{33}$ Peirce, ač již dříve mluví o znacích, jejich první komplexní klasifikaci stanovuje roku $1903^{34}$, přepracovává v roce 1908 a nikdy ji nedokončí. Jak poznamená Short (2007: 207), některé věci byly jasné od začátku: to, že je znak o sobě triadický, je v triadickém vztahu ke svému objektu a stejně tak k interpretantu. Zopakujme, že východiskem pro následující taxonomie jsou faneroskopické kategorie (máme tedy znaky ve své kvalitě, ve vztahu k objektu a ve vztahu k interpretantu). Pokud takto uvažujeme, je jasné, že znak sám (podle prvního dělení s ohledem na kvalitu) je „kvalita nebo obecný zákon“ (EP 2: 291). Je tedy Peircovým žargonem řečeno qualisignem, sinsignem, nebo legisignem, kde qualisignum je prostou kvalitou znaku, sinsignum je aktuální existencí (spojení qualisigna nebo, jak uvádí Peirce, spojením qualisignií - s nějakou konkrétní sémiosickou akcí), a nakonec tedy legisignum, které je „Zákonem“. Jak můžeme dovodit - je typem. Peirce jako př́klad uvádí (EP 2: 291) určitý člen v angličtině (the), který je ve své obecnosti právě takovým zákonem. Každé další užité „,the“ je pak replikou tohoto legisigna - sinsignem. Odtud také rozlišení známého type/token, které je v podstatě pojmenováním téhož, přičemž se však zapomíná na Peircovu uvedení tone, tedy opět kvalitativního rozměr znaku, nebo možnosti kompozice kvalit type vůbec.

$\mathrm{Z}$ tohoto důvodu nelze opět beze zbytku zaměnit Saussurovu a Peircovu perspektivu, totiž langue jako type a parole jako token. Jak vidno, Peirce zde uvažuje přesně podle zásad své faneroskopie - třetí (zákon jakožto znak) ve své artikulaci nutně předpokládá akci druhého (uskutečnění jakožto znak) a potencialitu prvního (kvalita jakožto znak). Pokud tedy uvažujeme relaci znak-znak, v rámci faneroskopie nabývá výše popsaných podob a nikdy se nejedná o transcendentální dyadickou relaci označující-označované. ${ }^{35}$

33 Prvně je třeba říci, že zde záměrně vynecháváme následující podstatné věci, které jsme tematizovali jinde, jako je Peircovo dělení sémiotiky na spekulativní gramatiku, kritickou logiku a čistou rétoriku, stejně tak Peircovo další dělení typů objektů (na dynamický a bezprostřední) a interpretantů (bezprostřední, dynamický a finální; emocionální, energetický a logický), a vůbec jeho nejpozdnější klasifikaci znaků (zejména v dopise Lady V. Welby a Williamu Jamesovi).

34 Ačkoliv je možné stopovat jeho základy k mnohem dřívějším textům, jak uvádí Karl’a (2015).

35 Což Peirce pochopitelně nediskvalifikuje z možné aplikace v rámci lingvistiky, nicméně je třeba vzít v úvahu diametrálně odlišnou perspektivu, než je prisma CLG (srov. Pharies 1985). 
Ikon

Pokud se tak v druhé instanci jedná o relaci znaku k objektu ${ }^{36}$ (tedy v žádném př́padě vztah označujícího a označovaného), jde o trichotomii ikonu (nikoliv ,ikony“), indexu a symbolu. Ikonické znaky sdílejí kvality se svým objektem (který však nemusí aktuálně existovat - jako je např. vyjádření geometrických vztahů obrazci, viz CP 2.304). Ikon je se svým objektem spojen pouty podobnosti, nikoliv však jako similarity, ale jako likeness. Ikonický znak sdílí se svým objektem soubor kvalit. Podle Peirce je např́klad fotografie z jisté perspektivy ikonem (EP 2: 13), to však neznamená, že je pouze (!) ikonem, ale jakožto otisk světla je pochopitelně indexem, znaky na fotografii jsou zároveň kvalitami, dále např. symbolickým vyjádřením jistých zvyklostí atd.

\section{Index}

Index je pak znakem spojeným s objektem na základě vztahu ,afekce“ (nikoliv pouze kauzality, viz CP 2.248). Peircův slavný př́klad je korouhvička ukazující směr větru, kdy, pokud chybí objekt (vítr), indexikální vztah zaniká (CP 2.304).

\section{Symbol}

Symbol je pak znakem spojeným s objektem na základě zákona, znakem vyjadřujícím ratio zastupovaného objektu - jinými slovy, symbol není nutně nějaké arbitrární (ve smyslu nemotivované) určení, ale naprríklad modus sylogismu. Symbol je na jedné straně věcí nějakého kódu (ve smyslu zákona), ale pro Peirce především kódu/zákonů logiky (potažmo sylogistiky). Rozdíl mezi legisignem a symbolem je pak ten, že symbol neoznačuje obecný zákon (interpretace), ale podobně jako index právě ten zákon, který je spojený s konkrétním objektem (např. daným sylogismem). Př́ikladem může být třeba vyjádření formy sylogismu modem BARBARA, kdy deduktivní sylogismus sám je obecným principem, tj. legisignem, a BARBARA symbolem pro tento modus. Jak vidno, jsme v př́padě symbolu na míle vzdáleni nějaké jednoduché představě konvenčnosti nebo dokonce libovůle - pro Peirce totiž je i např. př́rodní zákon věcí symbolu (srov. zejm. Stjernfelt 2007).

Třetí trichotomií, kdy se jedná o vztah znaku a interpretantu, je pak réma, dicisignum (nebo také dicentní signum nebo také kvazipropozice) a argument ${ }^{37}$. Réma je znakem, kdy objekt předpokládá takový znak, který determinuje takovou ideu, jejímž výsledkem je interpretant reprezentující kvalitativní možnost, dicisignum takový znak, který determinuje interpretant vztahující se ke skutečné možnosti, a nakonec argument, který je pro interpretanta zákonem (což je důležité odlišení oproti symbolu, kde se jedná o zastupování objektu znakem na základě zákona, zde jde o povahu interpretantu). Jinými slovy znak může být pojímán jako pojem (nebo nenasycená propozice), znak jako propozice a znak jako soubor premis a závěru (argument). „Nebo můžeme říci, že réma je znak, který lze chápat tak, že reprezentuje svi̊j objekt pouze v jeho rysech; že

36 A to dynamickému, viz CP $(8.334,8.335,4.536$ ad.), pro vysvětlení pojmu dynamického a bezprostředního objektu viz Švantner (2014a).

37 Nebo také: term, proposition, argument (CP 4. 538, 8.337), nebo později sumisignum, dicisignum, suasignum (EP 2: 275) nebo seme, pheme, delome (CP 4.538, EP 2: 481-490). 
dicisignum je znak, který lze chápat tak, že reprezentuje svi̊j objekt s přihlédnutím ke skutečné existenci; a že argument je znak, který lze chápat tak, že reprezentuje svým charakterem svůj objekt“ (CP 2.252). Z těchto tř́ triád pak Peirce dovozuje deset tříd znaku, které později rozvíjí a obměňuje, čemuž se zde věnovat nebudeme. Nutno také dodat, že tato taxonomie byla mnohokrát tematizována a v našem záměru je zde uvedena především jako demonstrativní (má ukázat lichost domněnky, že Peirce zavádí pouze druhou triádu, a že se jedná o komplexní systém).

\section{Sada kritik, komparace s prameny a vyvrácení omylů}

Po rámcovém, ale nutném představení základních paradigmat s ohledem na jejich prameny a redukovaném pro záměry tohoto textu je nabíledni, jaká konceptuální přehlédnutí některé studie přinášejí. Níže si je podrobně rozebereme.

\section{MCQuailovo dědictví}

Za prvotní kánon zmatení a zavádějících tvrzení ohledně sémiotiky v rámci mediálních studií lze považovat široce etablovanou knihu Denise McQuaila (2009), která dává podobně jako další populární kniha Terence Hawkese (1999) strukturalismus, sémiologii a sémiotiku pod jednu rubriku (McQuail 2009: 85; 357). Jak jsme viděli, toto smíšení je pro diametrální odlišnost perspektiv sémiologie a sémiotiky, stejně jako reinterpretace východisek sémiologie $\mathrm{v}$ různých strukturalismech, přinejmenším neopatrné a může vést (jako v případě níže zmíněných textů) k mnoha omylům. „Sémiotikosémiologii“ McQuail definuje následovně:

Věda o „znakových systémech“ nebo o „označování“. Vytvořil ji Ferdinand de Saussure při studiu obecné lingvistiky [...] Klíčovým prvkem sémiotiky je představa, že jakýkoliv (smysluplný) znak (jakéhokoliv typu) obsahuje prvek nesoucí význam a také jeho fyzický projev (slovo, obraz atd.). (McQuail 2009: 579)

Jedná se zde o zjevné směšování několika protichůdných pozic, přičemž nejdůležitější je tvrzení, že znak v prrípadě Saussurovy sémiologie nese nutně nějaký „fyzický projev“. Jak jsme ukázali výše, není to pravda. Saussure se věnuje znakům specifického (nikoliv jakéhokoliv) typu, totiž sociálně-psychologicky stanoveným mentálním jednotkám - „přirozené znaky“ (obecně znaky nějak motivované „Zvněǰšku“) nemají v jeho systému sémiologie žádný podstatný význam. Stejně tak je mimoběžná McQuailem chybně prezentovaná představa, že znak nese něco fyzického nebo že se dokonce označujicí rovná fyzickému prvku (McQuail 2009: 357). U Peirce je situace mnohem komplikovanější: triadická znaková relace je ontologicky indiferentní tomu, zda reprezentuje něco na mysli závislého nebo nezávislého, stejně tak zda znak sám je „pouhou“ myšlenkou, nebo např. zapsaným slovem. Není tedy pravda, co říká McQuail, když přesvědčuje čtenáře, že „[t] [̌ř zmínění teoretici [Peirce, Ogden-Richards a Saussure] používali některé stejné základní pojmy poněkud odlišným způsobem“ (McQuail 2009: 357); jak jsme podrobně ukázali výše, používali je způsobem zcela odlišným³.

38 Stejně jako v př́ípadě Peirce a Saussura nelze jednoduše zaměnit pozici Peirce a Charlese K. Ogdena a Ivora A. Richardse, př́padně Charlese W. Morrise nebo Rudolfa Carnapa. 
Vzhledem k předchozím analýzám analogicky neplatí McQuailův závěr, že znak je složen z označujícího a označovaného, které dohromady značí „vnější skutečnost“" (McQuail 2009: 358). Čtenáři je předestřen koncept „sémiotického trojúhelníku“ (McQuail 2009: 358, obr. 13. 1), kde autor spojuje saussurovské termíny s údajným označováním „vnější skutečnosti“ (kterou zde nazývá jako „referent“), což, jak jsme ukázali, je opět zcela v rozporu s tím, co tvrdí výše interpretovaní autoři ${ }^{39} \mathrm{~V}$ CLG se jedná o zjevné protiřečení jeho základním východiskům, u Peirce pak jde o neúměrné zjednodušení, u obou autorů pak o směšování pojmů. Označující a označované není representamen a interpretant, dokonce ani McQuailův „referent“, neodpovídá Peircově „objektu“. Směšují se jiné prvky, jiné relace a jiný zpo̊sob kombinace.

Podle McQuaila pak sémiologie/sémiotika proponuje skutečnost, že znak je „fyzický nositel významu v jazyce“ (McQuail 2009: 357). Jedná se opět o zavádějící tvrzení: v CLG je význam/hodnota znaku určená, nikoliv jeho „fyzickou existencí“, ale vztahem k celku systému (jak se snaží Saussure ukázat na slavném př́měru se šachovou hrou, viz CLG 43). U Peirce, zjednodušeně řečeno, je nositelem významu v širokém slova smyslu interpretant, tedy z hlediska sémiotiky jako meta-logiky jakožto jakákoliv virtuální determinace formálně stanovené kvazi-mysli.

Pokud se takto vágně (tj. bez ohledu na specifika pramenů, na které domněle odkazuje) „sémiotika/sémiologie“" stanoví, je snadné jí dále př̌isuzovat nejrůznější vlastnosti. ${ }^{40}$ McQuail přichází s vágní představou (těžko v jeho textu rozlišit, zda McQuail mluví obecně o sémiotice, nebo konkrétně o nějakém autorovi) o „sdělení komponovaném ze znakư“ (McQuail 2009: 85). Nelze tak jasně říci, jakou znakovou relaci má zde autor specificky na mysli, zřejmě se jedná o výše zmíněný konglomerát různých př́stupů. Namísto definování znakové relace nekriticky navazuje na v jádru již smíšenou post-marxistickou a ecovskou perspektivu Stuarta Halla (1980: 122), prezentovanou jako vágní sémiotický relativistický subjektivismus, podle nějž znaky mají údajně svůj denotát a konotované významy jsou závislé na volbě toho, kdo je dekóduje (McQuail 2009: 85-86). To lze z jisté perspektivy (např. solipsismu či psychologismu) jistě držet, nicméně s McQuailem popisovanými teoriemi znaku (Saussurem a Peircem, srov. McQuail 2009: 357) nemá tato perspektiva nic společného. I při velmi jednoduchém čtení Saussura i Peirce zjistíme, že oba autoři se (z různých pozic) právě tomuto subjektivismu, ústícímu do psychologistického relativismu, snaží vyhnout zavedením intersubjektivních a supra-subjektivních analytických nástrojů. Tím zásadním konceptuálním nástrojem je právě znak jako intersubjektivní (v případě Saussura) a suprasubjektivní (v př́ípadě Peirce) relace. Je možné jednoduše namítnout, že ani v širokém hnutí strukturalismu ani v peircovské tradici nejsou ,významy“ znaků závislé na volbě toho, kdo je dekóduje, stejně jako není totožné pojetí významu u Saussura a Peirce (tím méně u Umberta Eca a Stuarta Halla). ${ }^{41}$

39 Podobně zavádějící tvrzení o Peircově údajně „trojúhelníkové koncepci poznání“ nalezneme u Markové (2003: 78).

40 Je třeba dodat, že nešvarem mnohých podobných textů je neochota rozlišovat mezi sémiotikou a sémiosis, at’ už ve smyslu Peirce, nebo ve smyslu dalších tradic, kde se význam termínu ,sémiotika“ posouvá (např. u Louise Hjelmsleva nebo u Jurije Lotmana).

41 Pokud přisoudíme tzv. strukturalismu nějaký společný jmenovatel, tak je to právě snaha vyhnout se podobnému psychologismu - naopak, lakonicky vyjádřeno, pro strukturalismus báseň nepíše básník a jeho srdce, ale ,jazyk“ (jak vystihuje Descombes 1995). 
McQuail dále zaměňuje arbitrárnost znaku za „libovolnost“, jak jsme ukázali výše, zcela proti smyslu Saussurova konceptu. Tedy se opět nejedná o subjektivistickou libovůli. Pokud bychom McQuailovy vývody vzali do důsledků, ocitli bychom se v momentu zř́cení babylonské věže - přirozené jazyky nemohou existovat, stejně jako jakákoliv možnost strukturální analýzy, která se ve své obecnosti domnívá, že konkrétní fakta lidské činnosti podléhají nevědomým procesům, o kterých účastníci konkrétních komunikačních situací bud' radikálně neví (jako je tomu u nevědomí ${ }^{42}$ ), nebo je nemají v proudu řeči potřebu reflektovat. $\mathrm{Na}$ závěr svého exposé McQuail uvádí historicky nepravdivé tvrzení, že první, kdo se zaobíral konotací a denotací, byl Roland Barthes (McQuail 2009: 359). Je třeba dodat, že i denotace a konotace jsou problematické termíny nesoucí různé specifické významy s ohledem na koncepce, ve kterých jsou artikulovány (srov. Eco, Marmo 1989: 43-80).

Takováto sémiotika pak údajně „zdůrazňuje sílu zakódovaného textu a vnímá význam jako něco, co je do textu pevně zabudováno“ (McQuail 2009: 85-86). Student sémiotické epistemologie sociální vědy o médiích je dále (McQuail 2009: 356) přesvědčován, že „struktury jazyka“ tvoří znaky, př́běhy nebo mýty (bez bližšího vysvětlení), a dále, že strukturalismus tvrdí, že jazyky fungují díky „vestavěným strukturám“ (Ibid.). „Sémiotik“ je tak postaven do role astrologa nebo populárního symbolologa, tj. odhalovače „tajných významü“ (srov. Trampota, Vojtěchovská 2010: 118). To je přesný opak toho, za co lze strukturalistické výzkumy (které se např. v osobě Michela Foucaulta radikálně staví proti podobným mýtům filosofa jako odhalovače tajemství života) pokládat. Pokud McQuail označuje sémiologii za metodu, která údajně „ztratila na oblibě“, můžeme ironicky poznamenat, že možná právě z důvodu podobných konceptuálních zmatení (viz McQuail 2009: 357).

\section{Rozvíjení omylů}

McQuailovo matoucí zavedení sémiotických perspektiv do mediálně teoretických a mediálně-analytických koncepcí je naneštěstí širreno a nekriticky přebíráno. Instruktivní je v tomto směru kniha Tomáše Trampoty a Martiny Vojtěchovské (2010), která přebírá analogické omyly z McQuaila a z jiných českých knih, které sémiotiku zmiňují (jako Jirák, Köpplová 2003). Sémiotik je v těchto textech opět prezentován jako subjektivistický exegeta symbolů.

Znak je opět údajně složen ze své fyzické podoby, kterou vnímáme smysly, a označovaného (interpretovaného z vulgárního hlediska „co si pod tím kdo představí"), a skrze toto spojení probíhá zároveň propojení „nás“ a „reálného světa“ skrze tento znak (Trampota, Vojtěchovská 2010: 118). Jinými slovy, setkáváme se s míšením dvou naprosto odlišných perspektiv - saussurovských pojmů s torzem peircovského realismu (srov. Trampota, Vojtěchovská 2010: 119). Trampota a Vojtěchovská se pak, poté co odkáží na Saussura, zřejmě aby dali svému mis-konceptu patřičnou váhu, pouštějí na tenkou půdu interpretace Peirce. Čtenáře poučují o tom, že Peirce (který ke konci života přišel s 66 třídami znaků) rozlišil pouze třii: populární ikon, index a symbol, kdy údajně v první verzi se jedná o podobnost, ve druhé o kauzalitu, ve třetím o konvenci, přičemž podle tvrzení autorů „symboly mohou

42 Pro obsáhlý rozbor vztahu psychoanalýzy a strukturalistické tradice viz Fulka (2008). 
být slova." Pokud se podíváme do Peircova textu (který je dokonce přeložen do češtiny, viz Palek 1997), zjistíme, že se jedná přinejmenším o hrubé zjednodušení. Z představení uvedeném v knize se tak zdá, že Peirce nám přidal k Saussurově schématu slavné „něco navíc“, což je opět výsledkem nepochopení základních perspektiv, nebezpečného pro svou kanonizaci.

Další rozšířené omyly ohledně sémiotiky představuje kniha Masová média Jana Jiráka a Barbary Köpplové (2015), kde se kromě toho, že autoři bez jakékoliv reflexe přebírají zkreslení uvedená v jejich předchozí knize (směs peircovské a saussurovské terminologie) a zcela nekonzistentní prezentaci sémiotiky v McQuailovi, pouštějí na půdu dějin sémiotiky. Autoři nejprve definují sémiotiku pseudo-morrisovsky (kdy se vedle sémantiky a syntaktiky objeví i ztotožnění znaku s kódem, což je pojmenováno jako „pragmatika“), dále pak následuje postulát, že ze „sémiotického hlediska“ (které je v podání autorů utvořeno směsí nekonzistentního užívání pojmu a z kontextu vytržených konceptů) je vše textem, který je možno přečíst (Jirák, Köpplová 2015: 254). Což je do jisté míry vlastní některým proudům tzv. poststrukturalistických tradic, ale z hlediska Peircovy sémiotiky jde o přinejmenším velmi volnou interpretaci (opravdu slunečnice obracející se za sluncem „„̌te“?), kterou by bylo třeba vysvětlit a argumentačně cizelovat. Dále se bez jakéhokoliv odkazu na zmiňované filosofy dozvíme, že Aristotelés (v tomto př́padě tedy nejspíše někde ve spise $O$ Vyjadřování a v Prvních analytikách, kde představuje dvě odlišná pojetí toho, co je znak a jaká je jeho typologie) se domníval, že „významy slov vznikají dohodou a že jsou konvencializované, nikoliv ,pririrozené' (dané povahou označovaného)“ (Jirák, Köpplová 2015: 254). Nejenže je velmi problematické mluvit o Aristotelově koncepci formou saussurovského slovníku (,označované“), ale to, co autoři tvrdí, není jednoduše pravda, a to z mnoha důvodů, o kterých jsme pojednali jinde. ${ }^{43}$ Pouze poznamenejme, že tato zjednodušení ignorují specifický význam řeckých termínů sémeion (kdy se jedná o prrirozené znaky) a symbolon (který nelze ztotožnit s představou prostého konvencionalismu). Následují dějiny v kostce, prezentované velmi schématickým a zavádějícím způsobem, kdy se autoři domnívají, že stoici (kteří přišli s myšlenkou, že „,nevyjadřujeme věci, ale výpovědi“) rríkají „něco podobného“ co Ogden-Richards; autoři dále šiří ideu, že jejich verze sémiotického trojúhelníku odpovídá stoikům, aniž by měli potřebu odkázat na stoické zlomky či alespoň na dnes kanonickou studii o teorii znaku v antice Giovanniho Manettiho (1995) atd. Signálem nepř́ilišného zájmu o přesnou interpretaci historie sémiotiky je ten fakt, že ačkoliv autoři zmíní Johna Locka, nezmíní to, že právě on je (vedle latinských lékařů) autorem termínu „sémiotika“. Čtenáři jsou dále představeny překvapivé postuláty, které by bylo třeba minimálně dovysvětlit, jako např. to, že znakový systém je dostupný pouze studiem konkrétních projevů - těžko říci, zda i tak pokročilá věda, jako je historická lingvistika, si může poslechnout konkrétní projevy keltštiny nebo praindoevropštiny. Autoři dále tvrdí, že v saussurovské tradici se sémiotika rozvíjela především jako metoda analýzy přirozeného jazyka coby systému znaků nesoucích význam. Přičemž podíváme-li se na nejsilnější tradici radikálně následující Saussura, tedy Kodaňskou školu,

43 Viz Hanke, Kastnerová, Větrovcová, Švantner (2015), Charvát, Karl’a, Švantner (2015). U Aristotela jde totiž v případě jeho lingvistické teorie znaku o směs „konvence“ (psané nebo mluvené znaky označují trpná hnutí duše na základě „,dohody“) a „motivovanosti“ (hnutí duše jsou afikována ,ikonicky“ věcmi). Viz k tomuto Manetti (1995: 70-90). 
zjistíme, že činila pravý opak - glosématika se ustanovila především jako metoda výzkumu abstraktních a formálních jazykových struktur.

Jsou však texty, které jdou v kreativitě ještě dále, pokud hovoří o znacích, bud’ raději prameny vůbec nezmiňují (Musil 2010), nebo již nepřesně interpretované dále posouvají, jako je tomu v př́padě Psychologie komunikace (Vybíral 2000). V této publikaci, která chce mj. vysvětlit komunikaci na sémiotickém základě, text čtenáře poučuje, že Saussure řešil model znaku jako Peirce, kdy „za označující považoval fyzickou existenci znaku“ a proces signifikace údajného Saussura chce prý označovat „vnější skutečnost, resp. význam“ (Vybíral 2000: 225). Dozvíme se, že Peircova „ikona“ je např. „smajlík“, a co je závažnější, že v případě ikonu, indexu a symbolu jde o vztah mezi označovaným a označujícím. Text pokračuje karikováním autorů poněkud eristickým způsobem. Čtenáře, který si má představit údajný fakt toho, že „označující“ může ,podstatnou měrou determinovat označované (a tedy skutečnost)“, tak uvádí v podstatný omyl. Zřejmě opět z toho důvodu, že bud’ Peirce a Saussura nečetl, nebo vychází z nevalných sekundárních zdrojů.

\section{Závěr}

Zde výčet uzavřeme, každý čtenář si může provést miniaturní výzkum/rešerši, postaví-li se v místní vědecké knihovně před polici se sociálními vědami a namátkou si vybere knihy, které spiše než by sémiotiku hlouběji tematizovaly, ji pouze zmiňují. Pokud sémiotika a sémiologie získala pověst zmateného, vágního hovoření o znacích, tak vinu nesou do jisté míry právě podobné texty, a je třeba, aby podobná zmatení byla vynesena na světlo i za cenu toho, že takový podnik připomíná dva o sebe opřené opilé námořníky (CP 8. 167). Takovou sémiotiku totiž nečeká jiný osud než onu pověstnou tvář nakreslenou v písku, kterou postupně smývá mořský príboj.

\section{Literatura}

AARSLEFF, Hans. 1982. From Locke to Saussure: Essays on the Study of Language and Intellectual History. Minneapolis: University of Minessota Press.

ABOULAFIA, Mitchell et al. 2012. Habermas and Pragmatism. London: Oxford University Press.

AMSTERDAMSKA, Olga. 1987. Schools of Thought: The Development of Linguistics from Bopp to Saussure. Dordrecht: D. Reidel.

ANDERSON, Douglas R. a Carl R. HAUSMAN. 2012. Conversations on Peirce. Reals and Ideals. New York: Fordham University Press.

APEL, Karl-Otto. 1973. Transformation der Philosophie II. Frankfurt: Suhrkamp.

APEL, Karl-Otto. 1975. Der Denkweg von Charles S. Peirce. Eine Einfiihrung in den amerikanischen Pragmatismus. Frankfurt: Suhrkamp.

APEL, Karl-Otto. 1995. „Transcendential Semiotics and Hypothetical Metaphysics of Evolution: A Peircean or Quasi-Peircean Answer to a Recurent Problem of Post-Kantian Philosophy.“ Pp 366-386 in Kenneth KETNER (ed.). Peirce and Contemporary Thought. New York: Fordham University Press.

ARDENER, Edwin (ed.). 2013. Social Anthropology and Language. London: Routledge. 
BERTILSSON, Thora Margareta. 2009. Peirce's Theory of Inquiry and Beyond: Towards a Social Reconstruction of Science Theory. Frankfurt: Peter Lang.

BIGNELL, Jonathan. 2002. Media Semiotics. Manchester: Manchester University Press.

BOURDIEU, Pierre. 1998. Teorie jednání. Praha: Karolinum.

BURKS, Arthur a Paul WEISS. 1945. „Peirce's sixty-six signs.” Journal of Philosophy 42(12): 383-388.

COLAPIETRO, Vincent. 1987. „Semiosis and Subjectivity: A Peircean Critique of Umberto Eco.“ Southern Journal of Philosophy 25(3): 295-312.

ČERNÝ, Jiř́ a Jan HOLEŠ. 2004. Sémiotika. Praha: Portál.

DAYLIGHT, Russel. 2011. What if Derrida was wrong about Saussure? Edinburg: Edinburg University Press.

DERRIDA, Jacques. 1999. Gramatológia. Bratislava: Archa.

DESCOMBES, Vincent. 1995. Stejné a jiné: Čtyřicet pět let francouzské filosofie. Praha: OIKOYMENH.

ECO, Umberto a Constantino MARMO (eds.) 1989. On the Medieval Theory of Signs. Amsterdam: John Benjamins.

ECO, Umberto. 2005. Meze interpretace. Praha: Karolinum.

ECO, Umberto. 2009. Teorie sémiotiky. Praha: Argo.

ECO, Umberto. 2011. Kant a ptakopysk. Praha: Argo.

ENIKO, Nemeth T. 2006. „Saussure and Chomsky: The Distinctness of Their 'Identical' Views.“ Central European Journal of Social Sciences and Humanities 102(4): 420-430.

FOUCAULT, Michel. 2000. Slova a veci. Bratislava: Kalligram.

FULKA, Josef. 2008. Psychoanalýza a francouzské myšlení. Praha: Herrmann \& synové.

GVOŽDIAK, Vít. 2012. Jakobsonova sémiotická teorie. Olomouc: Nakladatelství Univerzity Palackého.

GVOŽDIAK, Vít. 2014. Základy sémiotiky 1, 2. Olomouc: Nakladatelství Univerzity Palackého.

HALL, Stuart. 1980. „Encoding/decoding“. Pp. 117-126 in Stuart HALL et al. (eds.). Culture, Media, Language. New York: Routledge.

HANKE, Miroslav, Martina KASTNEROVÁ a Martin ŠVANTNER. 2015. Stopování sémiotiky. Červený Kostelec: Pavel Mervart.

HARRIS, Roy. 1987. Reading Saussure: a Critical Commentary on the Cours de linguistique générale. London: Duckworth.

HARRIS, Roy. 1990. Language, Saussure and Wittgenstein: How to Play Games with Words. London: Routledge.

HARTSHORNE, Charles. 1984. Creativity in American Philosophy. Albany: SUNY.

HAWKES, Terence. 1999. Strukturalismus a sémiotika. Brno: HOST.

HOOKWAY, Christopher. 2002. Truth, Rationality, and Pragmatism: Themes from Peirce. Oxford: Clarendon Press.

HOSKOVEC, Tomáš. 2008. „Od významu v jazyce ke smyslu v textu. O dobrodružství strukturalistické cesty." Slovo a slovesnost 69(1-2): 110-130.

HUTTON, Christopher a Adrian PABLE. 2015. Signs, Meaning and Experience: Integrational Approaches to Linguistics and Semiotics. Berlin: Walter de Gruyter.

CHARVÁT, Martin, Michal KARL'A a Martin ŠVANTNER. 2015. Archeologie znaku. Vybrané studie $k$ dějinám sémiotiky. Praha: Togga.

CHROMÝ, Jan. 2014. Komunikace, média, vzdělávání, kultura. Praha: Extrasystem.

JIRÁK Jan a Barbara KÖPPLOVÁ. 2003. Média a společnost. Praha: Portál.

JIRÁK Jan a Barbara KÖPPLOVÁ. 2015. Masová média. Praha: Portál.

JOAS, Hans. 1993. Pragmatism and Social Theory. Chicago: Chicago University Press.

KARLA, Michal. 2015. „Peirce's Doctrine of Man-Sign and its Logical Antecedents.“ The American Journal of Semiotics 31(3-4): 277-284. 
KETNER, Kenneth L. a Christian J. W. KLOESEL (eds.). 1986. Peirce, Semeiotic and Pragmatism: Essays by Max H. Fisch. Bloomington: Indiana University Press.

KLINKENBERG, Jean-Marie. 2014. „O kognitívnej semiotike.” Filozofia 69(1): 22-32.

KRAMPEN, Martin et al. 1987. Classics of Semiotics. Berlin: Springer.

LÉVI-STRAUSS, Claude. 2009. Strukturální antropologie. Praha: Portál.

LOTMAN, Jurij M. 1991. Universe of the Mind. A Semiotic Theory of Culture. Bloomington: Indiana University Press.

MANETTI, Giovanni. 1995. Theories of the Sign in Classical Antiquity. Bloomington: Indiana University Press.

MARKOVÁ, Ivana. 2003. Dialogičnost sociální reprezentace: dynamika mysli. Praha: Academia.

McQUAIL, Denis. 1997. Úvod do teorie masové komunikace. Praha: Portál.

McQUAIL, Denis. 2009². Úvod do teorie masové komunikace. Praha: Portál.

MITOSEKOVÁ, Zofia. 2009. Teorie literatury: historický přehled. Brno: HOST.

MUSIL, Josef. 2010. Sociální a mediálni komunikace. Praha: Univerzita Jana Amose Komenského.

NORMAND, Claudine. 2006. „System, arbitrariness, value.” Pp. 88-104 in Carol SANDER (ed.).

Cambridge Companion to Saussure. Cambridge: Cambridge University Press.

OGDEN, Charles K. a Ian A. RICHARDS. 1923. The Meaning of Meaning. New York: Harcourt.

PALEK, Bohumil. 1997. Sémiotika. Praha: Karolinum.

PARRET, Herman. 1976. History of Linguistic Thought and Contemporary Linguistics. The Hague: Walter de Gruyter.

PEIRCE, Charles Sanders. 1931-1958. Collected Papers of Charles Sanders Peirce. Editovali Charles HARTSHORNE, Paul WEISS a Arthur W. BURKS. Cambridge (MA): Harvard University Press.

PEIRCE, Charles Sanders. 1976. New Elements of Mathematics. New York: Hartcourt.

PEIRCE, Charles Sanders. 1980-. The Writings of Charles Sanders Peirce: A Chronological Edition. Bloomington: Indiana University Press.

PEIRCE, Charles Sanders. 1992. Essential Peirce, I-II. Bloomington: Indiana University Press.

PHARIES, David A. 1985. Charles Sanders Peirce and Linguistic Sign. Amsterdam: John Benjamins.

POLIDORO, Piero. 2015. „Umberto Eco and the problem of iconism.“ Semiotica 206: 129-160.

PRONI, Giampalo. 2015. „Umberto Eco and Charles Peirce: A slow and respectful convergence.“ Semiotica 206: 13-35.

SAUSSURE de, Ferdinand. 1989. Cours de linguistique générale. Edition critique. Wiessbaden: Otto Harrassowitz.

SAUSSURE de, Ferdinand. 2007. Kurs obecné lingvistiky. Praha: Academia.

SHORT, Thomas L. 2007. Peirce's Theory of Signs. Cambridge: Cambridge University Press.

SIMONE, Raffaele. 1992. „Montrer au Linguistique ce qu'il fait. Une analyse épistémologique du structuralisme européen (Hjelmslev, Jakobson, Martinet, Benveniste) dans sa filiation saussurienne.” Pp 174-196 in Raffaele SIMONE. II sogno di Saussure. Bari: Laterza.

STAWARSKA, Beata. 2015. Saussure's Philosophy of Language as Phenomenology Undoing the Doctrine of the Course in General Linguistics. New York: Oxford University Press.

STJERNFELT, Frederik. 2007. Diagrammatology. An Investigation on the Borderlines of Phenomenology, Ontology and Semiotics. Berlin: Springer.

ŠVANTNER, Martin. 2014a. „O jedné bouři v čajovém hrnku: Ch. S. Peirce, U. Eco a sémiotická metafyzika objektů.“ Filozofia 69(1): 63-76.

ŠVANTNER, Martin. 2014b. „Struggle of a description: Peirce and his late semiotic.“ Human Affairs 24(2): 204-214.

THIBAULT, Paul J. 1997. Re-reading Saussure. The dynamics of signs in social life. London: Routledge. TRAMPOTA, Tomáš a Martina VOJTĚCHOVSKÁ. 2010. Metody výzkumu médii. Praha: Portál. VYBÍRAL, Zbyněk. 2000. Psychologie komunikace. Praha: Portál. 


\section{Autor}

Martin Švantner působí na Katedře elektronické kultury a sémiotiky Fakulty humanitních studií Univerzity Karlovy v Praze a Katedře sociologie Filozofické fakulty Západočeské univerzity v Plzni, kde se věnuje dějinám sémiotiky, teorii znaku C. S. Peirce, pragmaticistně orientované teorii argumentace a sociálněvědní epistemologii. Je spoluautorem knih Archeologie znaku a Stopování sémiotiky.

Kontakt: Svantner.M@seznam.cz 